\title{
Review of periodical articles
}

Frederik Buylaert, Jim Van Der Meulen, Gerrit Verhoeven, Reinoud Vermoesen and Tim Verlaan

Ghent University, Department of History, Henri Pirenne Institute for Medieval Studies,

Sint-Pietersnieuwstraat 35, B-9000 Ghent, Belgium

Ghent University, Department of History, Henri Pirenne Institute for Medieval Studies,

Sint-Pietersnieuwstraat 35, B-9000 Ghent, Belgium

Department of History, University of Antwerp, 2000 Antwerp, Belgium

Centre for Urban History, University of Antwerp, Prinsstraat 13 (D. 308), 2000 Antwerp, Belgium

Faculty of Humanities, Vrije Universiteit Amsterdam, De Boelelaan 1105, 1081 HV Amsterdam,

The Netherlands

\section{Pre-1500}

The topic that dominates hearts and minds in 2020 is of course the COVID-19 pandemic, and historians have not been idle in the fierce debates about the origins, nature and consequences of this development. As much of post-war scholarship revolved around the ambition to rid our profession of older practices in which historical studies were weaponized by states and nations, historians are rightfully cautious not to fall into the same trap and to lend their voice to the many interest groups that now have to reposition themselves in the wake of COVID-19. Then again, it is encouraging to see that historians are not retreating to the Ivory Tower, but that they are developing an ambitious programme: as Sujit Sivasundaram argues in the pages of Past \& Present, the aim is not to just provide facile comparisons of our current travails with earlier epidemics, but to probe human engagement with natural environments as a cultural artefact with a complex and multifaceted history of its own ('The human, the animal and the prehistory of Covid-19', Past \& Present, 294 (2020), 295-316).

In the past year, medievalists have developed some extremely valuable contributions to this important project, two of which revolve around the mother of all pandemics, the Black Death. The first is a revisionist article by Guy Geltner on responses to the Black Death. Proceeding from a re-reading of a set of health measures published in the Tuscan town of Pistoia (situated between Pisa and Florence) that has traditionally been read as an ineffective ad hoc response to the onset of the Black Death in 1348, he argues that earlier scholarship has greatly underestimated the extent to which towns had committed to 'healthscaping' in the preceding two centuries. Burgeoning towns such as Pistoia, which reached a population zenith of c. 11,000 around 1300, were long-accustomed to issuing and enforcing public health measures that ranged from labour regulations to a wide array of guidelines for the meat packing industries and the disposal of human waste, including human corpses. Crucially, contemporaries proceeded from Galenic assumptions about humours that left little room for the current conceptual distinction between public health and civic order, so that thirteenth-century sanitary regulations segued organically from measures against 'bad vapours' into district zoning policies or the infrastructural planning for the influx and outflux of capital, goods and humans in the town ('The path to Pistoia: urban hygiene before the Black Death', Past \& Present, 246 (2020), 3-33).

(C) The Author(s), 2021. Published by Cambridge University Press. 
This insightful approach that pays considerable attention to the spatial aspects of urban history tallies well with two articles that focus directly on the production and consumption of urban space. The somewhat descriptive article of Veronika Novák explores how royal officials in late medieval Paris organized the oral dissemination of ordinances through public declarations on well-chosen spots in the capital, a practice that can be traced through some 250 references in the so-called Livres de couleur of the Paris Châtelet ('L'espace du cri à Paris aux XIVe-XVIe siècles: recherches sur les "lieux accoutumés", Revue Historique, 696 (2020), 61-86). Next to this, there is the methodologically interesting contribution of Justin Colson on social and geographical relationships between residents of the late medieval City of London. Colson seeks to refine the usage of Geographic Information Systems (GIS) in historical analyses of spatial and social affiliations between urbanites, remarking that 'historians seldom, if ever, make use of the formal tools offered in GIS to identify, measure and quantify these phenomena'. This is largely a consequence of the tension between the 'fuzzy' spatial terminology of late medieval records and the precise location points of ('Cartesian') GIS. Colson demonstrates that the visualization of spatial data through GIS can help to guide qualitative interpretations of spatial phenomena, as long as historians adopt 'a suitably nuanced and sensitive approach to what the results can, and cannot, tell [them]'. Focusing on the choice of witnesses and executors in fifteenth-century property deeds and wills, he reveals that the social networks of City residents closely intersected with their geographical networks. However, when choosing a witness to a property deed, possession of 'local knowledge' was deemed more important than proximity to the property in question. In a similar vein, people primarily chose the executors of their will based on their membership of the same trade or occupation, but these were often (at least 35-60 per cent of the time) also their neighbours or fellow parishioners. Thus, social relationships and geographical affiliations were tightly enmeshed in the late medieval city ('Reinterpreting space: mapping people and relationships in late medieval and early modern English cities using GIS', Urban History, 47 (2020), 384-400). These observations on how ordinary city dwellers navigated the intersections between professional occupations and the organization of urban space help to understand why health policies were inextricably entwined with urban planning and logistics management for urban governments such as that of Pistoia.

The other major contribution on how medieval towns responded to the acute health crisis that was the Black Death comes from Abigail Agresta, who provides an incisive exploration of public responses to the recurrent plague epidemics in the Aragonese town of Valencia (situated on the east coast of Spain) in the fourteenth and fifteenth centuries. Here too, the urban authorities proceeded from a perspective towards minds, bodies and the natural world that stressed the overlaps between, on the one hand, moral hazards, and, on the other hand, threats to public health that inevitably stemmed from the combination of dense populations with high circulations of humans, animals and objects. Just as in Pistoia, the inhabitants of Valencia were preoccupied with the work of butchers and undertakers, as well as with blasphemy and sodomy (an umbrella term for a wide range of activities other than procreative sex), as well as the stigmatized activities of gamblers, pimps and prostitutes, who often belonged to Valencia's immigrant poor. Unlike other disasters 
such as floods or droughts, the plague was conceived as a divine punishment that demanded practical and moral reform of the urban community. Only from the midfifteenth century onwards did attitudes change, at least among the urban elites. Borrowing ideas via the dynastic union of Aragon, Sicily and Naples and from the efflorescence of medical sciences in Valencia, the aldermen were prone to reimagine the threat as an external rather than an internal threat. For them, the root cause was no longer the moral corruption of the urban community, but rather the result of contagious outsiders, whereas the town's lower orders clung to ideas in which pestilence and moral rot were inextricably entwined. Perhaps most interesting of all is that moral rot was a fairly inclusive concept. Rather than scapegoating the extensive communities of Muslims and Jews - the Valencia hinterland belonged to a part of a Christian kingdom where the Christian population was itself a minority group moral crisis and moral restoration were imagined as the project of the entire urban community ('From purification to protection: plague response in late medieval Valencia', Speculum, 95 (2020), 371-95).

Unfortunately, the issue of scapegoating minorities was another persistent theme in 2020, ranging from the legal stigmatization of the LGBT+ communities in several Eastern European polities to the even more widespread backlash against immigrants. This brings into focus another noteworthy contribution, namely a synthetic essay on immigration in medieval England by Mark Ormrod, whose death in August 2020 was a great blow to the international community of medievalists. Pitching the results of one of his last great research projects, Ormrod explores whether the anti-immigration strand of ongoing debates on Brexit has a 'Deep History' with a discussion of immigration to England in the fourteenth to midsixteenth centuries as well as of the attitudes of the indigenous population to these immigrants. Unique fiscal records produced by the English crown reveal that, around 1440, about 30,000 of the 2-2.5 million inhabitants (c. 1.2-1.5 per cent) of England were immigrants who hailed mainly from Scotland, Ireland, France, the Low Countries, the German Empire and Italy. Unsurprisingly, immigrant populations were concentrated on the northern border with Scotland and in southern England. Also, as many immigrants had been lured to England by the acute need for skilled labour in the third quarter of the fourteenth century, they tended to cluster in towns, where the share of immigrants in the population was often double that of the national average. Taking stock of the available evidence and drawing on the long-standing debates on xenophobia in early modern England, Ormrod argues that English responses to immigrants in their midst were characterized by 'a conditional but continued permissiveness around the involvement of aliens in the economy', and that this structural co-existence persisted even when the crown adopted protectionist policies. This is not to deny that this permissiveness was sometimes punctured by a brutal backlash against immigrants, but Ormrod points out that anti-immigration rhetoric - a discourse that was apparently as conducive to violence as it is now - was usually carefully cultivated by specific interest groups such as urban guilds who hoped to eliminate doughty economic competitors ('England's immigrants, 1330-1550: aliens in later medieval and early Tudor England', Journal of British Studies, 59 (2020), 245-63).

The ways in which local communities defined their own identities was not only about articulating a view on immigrants, however, but also about how these 
communities situated themselves on their mental map of the world, and this too has a history of its own. Cecilia Gaposchkin makes this point effectively by zooming in on the French town of Soissons. In late antiquity, Soissons had developed into a fairly important episcopal town, with the town's main church being dedicated to the worship of Gervais and Protais, two Milanese saints who were firmly grounded in the history of the old Merovingian polities. This situation changed considerably, however, at the turn of the thirteenth century. Construction of its now famous new cathedral had started, and to boost the church, local noblemen secured for Soissons some of the new relics that had come into circulation after the notorious sack of Constantinople and its churches in the Fourth Crusade of 1204. The Soissons liturgy, including the organization of processions in the town, was now revamped to give centre stage to relics of saints such as St John the Baptist, who enjoyed a far greater acclaim in the Christian world than Gervais and Protais. As a result, the inhabitants of Soissons felt closer to the cradle of Christianity, and their mental map was adjusted accordingly as the 'new liturgy shifted the city's sacral narrative from local to universal history; backward in time and eastward in space, into the biblical past...With the relics of these biblical, universal saints, Soissons then made a claim to be successor to Constantinople and on a par with Rome as a sacred city, not only of Gaul but in all Christendom' ('Nivelon de Quierzy, the cathedral of Soissons, and the relics of 1205: liturgy and devotion in the aftermath of the Fourth Crusade', Speculum, 95 (2020), unpaginated online pre-print). As with the other pieces discussed above, this contribution makes clear that there is still much mileage in the so-called spatial turn among medievalists, and that its implications are considerable for ongoing debates on identity formation as a relational process: 'othering' immigrants, to return to Ormrod's example, proceeds from assumptions about one's own place in time and space and vice versa, and an entangled history of both processes appears a worthy goal for future research on medieval towns.

Another major contribution to the history of othering in medieval towns proceeds from a gender perspective on credit markets. This subject is greatly understudied, but important new research has been published by Andrea Bardyn for the Brabantine towns of Antwerp and Leuven. Her comparative approach is particularly interesting because of the divergent trajectories of both towns: whereas Antwerp gradually morphed into the dominant gateway town of the Low Countries, including a population boom from $c$. 10,000 in 1400 to $c$. 37.000 in 1490, Leuven saw its economic fortunes plummet, a development that was mirrored in a demographic decline from c. 22,000 inhabitants in c. 1450 to 15,000 in c. 1490. Careful sifting of the available records on credit transactions allows Bardyn not only to put to rest the cliché that women only engaged in credit relations with other women, but also to conclude that the involvement of women in credit markets in Antwerp and Leuven - women provided c. 13-15 per cent of the creditors and $c$. 1-4 per cent of debtors - was no greater than in other parts of Europe, a claim that challenges a recently influential narrative in which the precocious economic development of the late medieval Low Countries is largely rooted in the supposedly greater agency of women. A second major conclusion of this incisive paper is that the greatly different circumstances of the Antwerp and Leuven economies influenced the position of women on the credit market. In the boom town of Antwerp, lending money was not only the privilege of rich spinsters or widows, but also of married 
women, and whatever their marital status, the constant hunger for capital to finance commerce allowed these women to charge the same interest rates as men. In contrast, female involvement in the Leuven credit market was more constrained: women only lent out smaller sums of money, and the cards were so stacked against them in an economy in decline with limited demand for credit that they had to be satisfied with lower interest rates than the ones charged by male creditors. In sum, this research does much to reveal the contours of patriarchy in Netherlandish towns, while historians with other specialisms than Netherlandish history will be interested in the conceptual interplay between social and economic configurations and gender inequalities ('Constrained opportunities: women's involvement in the capital markets of late medieval Brabant', Social History, 45 (2020), 275-303).

Another important and elegant contribution in this respect is Justine Firnhaber-Baker's article on the social profile of the participants in the famous Jacquerie Revolt in France in the summer of 1358, as this article contains a sophisticated discussion about what can and cannot be said about the involvement of women in this revolt on the basis of a limited set of primary sources with a bent towards the under-registration of female agency. For urban historians, this contribution is important because Firnhaber-Baker's research confirms the close collaboration between, on the one hand, the rural Jacques, and, on the other hand, the rebels in Paris under the leadership of Etienne Marcel. Amiens and Senlis also stand out as bulwarks of what is traditionally imagined as a rural revolt, but which turns out to have transcended the divide between town and countryside ('The social constituency of the Jacquerie Revolt of 1358', Speculum, 95 (2020), 689-715).

Etienne Marcel and his fellow rebels are a forceful reminder that even in a kingcentred realm such as Île-de-France, urban elites had their own agenda, distinct from that of the prince and the princely administration, and that the traditional entente between late medieval rulers and local elites was often upended by fierce confrontations. This topic also resurfaces in a special section in Urban History on Netherlandish and English urban elites that was brought together by one of the authors of this section of the review. Covering the case-studies of Ghent, Bruges, Mechelen and Antwerp in both detailed articles and a comparative synthesis, this research suggests that the traditional framing of Netherlandish urban elites as 'patriciates' - a term borrowed from Roman antiquity - is not particularly helpful, in that it shields from view the intense changes in the social profile of urban ruling classes. Quantitative and qualitative evidence suggests that the social turnover among leading families was much higher than earlier generations of scholars suspected, and the profile of these families became more heterogeneous, not in the least because of the growing influx of landed nobles who wished to participate in urban life and urban politics. As a result, Netherlandish elites show considerable similarities to English urban elites, an observation that does not sit well with a longstanding tradition that imagines the English trajectory of urban government as exceptional (Frederik Buylaert, Jelten Baguet and Janna Everaert, 'Returning urban political elites to the research agenda: the case of the Southern Low Countries $(c .1350-c .1550)$ '; Janna Everaert, 'Power in the metropolis: the impact of economic and demographic growth on the Antwerp City Council (1400-1550)'; Frederik Buylaert, 'From periphery to centre and back again: elite transformations in Mechelen (fourteenth to sixteenth centuries)'; Jelten Baguet, 'The 
rransformation of an urban political elite: oligarchy and aristocracy in sixteenthcentury Ghent'; Christian D. Liddy, 'Family, lineage and dynasty in the late medieval city: re-thinking the English evidence', Urban History, 47 (2020), 568-670).

Of course, the urban sphere was not solely given shape by the lay elites. The past year saw a number of notable contributions on the role of various other stakeholders in economic and political interactions within medieval towns. For starters, Samantha Kahn Herrick offers an interesting - and highly amusing - perspective on the ways in which suburban monasteries laid claim to economic rights and authority over urban space in the high medieval period. In twelfth-century Metz, the monks of St Clément pursued an array of inventive, if questionable, strategies to emerge victorious in the tug-of-war of intra-urban competition in this city that 'became one of the most important economic centres in the region'. Battling against other religious institutions, lay authorities and local traders alike, the monks of St Clément tried to consolidate their power over Metz's expanding urban populace and space, amongst other things by founding new parishes and instituting annual fairs. In doing so, neither they nor their competitors pulled any punches in order to get what they wanted. From bribing representatives of the bishop, over forging legal documents that underpinned their claims of authority, to drafting equally spurious hagiographies that embedded these claims in 'sacred history': these monastic machinations 'reveal the fraught and contested nature of urban growth' at the start of the commercial revolution (Samantha Kahn Herrick, "Very great strife": the monks of Saint-Clément as competitors in twelfth-century Metz', Journal of Medieval History, 46 (2020), 536-51).

Much as these twelfth-century monks strove to leave their mark on the expanding urban fabric, so did the struggle of merchants and craft organizations for political and economic prominence in the towns of the later Middle Ages. In this regard, economic historians have long been aware of the prominent role of the textile industries and textile trade. A relatively understudied group of artisans, however, are the fullers, that is, the people responsible for washing, shrinking, felting and stretching woven cloth in order to make the fabric more durable. The fullers have largely eluded scrutiny because they were often among the least politicized of the textile crafts and have therefore left fewer traces in the record. However, through a systematic analysis of fullers' positions in several English towns (London, Winchester, Colchester, Norwich), Milan Pajic convincingly argues that this group of artisans did in fact enjoy a brief period of economic and political efflorescence around the middle of the fourteenth century. Pajic shows a steady increase of fullers among the English urban population, as well as their growing political influence (e.g. their seat on the Common Council of London from 1376). He attributes this development to a late medieval bifurcation of the textile economy, in which urban producers increasingly turned to the manufacture of high-quality cloth - finished by labour-intensive foot-fulling - while rural artisans shifted to the production of coarser woollens that were mechanically fulled in mills - thereby pushing rural fullers to the towns. ${ }^{1}$ The rising demand for fulled cloth in

\footnotetext{
${ }^{1}$ These findings complement those recently made for the English countryside: J. Oldland, The English Woollen Industry, c. 1200-c. 1560 (Abingdon, 2020); idem, 'The clothiers' century, 1450-1550', Rural History, 29 (2018), 1-22.
} 
the fourteenth century gave these fullers a better bargaining position in the urban textile trade, which they were able to exploit successfully for some time - that is, until their entrepreneurial position was usurped by the English drapers around 1400 ('The fortunes of urban fullers in fourteenth-century England', Historical Research, 93 (2020), 227-51).

Textile entrepreneurship is also the central theme of an engaging article by Jean-Louis Roch on late medieval Rouen. Roch offers a contribution to the debate on the economic development of the pre-industrial city by focusing on the question how the cloth trade of Rouen and its hinterland were organized. The most thoughtprovoking aspect of this article is that the author entertains the notion that Rouen's cloth trade shared a common ground with the 'bazaar economies' of Northern Africa and Western Asia, an experiment in which Roch acknowledges the influence of Clifford and Hildred Geertz's anthropological study of Moroccan society. ${ }^{2}$ While Roch ultimately concludes that Rouen was closer to a centre of 'small commodity production' such as predominated in certain cities in the medieval Low Countries (Leiden, Lille), he emphasizes that the urban artisans and entrepreneurs were very flexible in their organization and adopted a multiplicity of 'petits arrangements' to suit their convenience. Wherein the textile economy of Rouen resembled a bazaar economy, was its non-hierarchical nature and the prominent role of informal networks of merchants and artisans. Where the trading sites of Rouen differed from contemporary bazaars or souks, however, was in their relatively uniform prices and the fact that these 'halles' did not double as workshops, homes or spaces for social gatherings - key characteristics of the bazaar. Thus, this essay implicitly ties in with the framework of New Institutional Economics (NIE) in economic history, but is innovative in its focus on the informal aspects of commerce in the medieval city - whereas proponents of NIE predominantly focus on the formal rules of trade ('Artisans ou marchands: la draperie médiévale de l'Italie à la Normandie', Revue historique, 695 (2020), 39-58). ${ }^{3}$

These informal, personal aspects of trade, then, carry through in two contributions that focus on everyday material culture in the medieval city. Elizabeth Gemmil provides a thorough pilot study on the Scottish city of Aberdeen. Instead of a more traditional corpus consisting of archaeological objects, Gemmil uses a variety of written evidence (lawsuits, probate inventories and byelaws about the conduct of trade) to show the 'quickening of commercial life' in Aberdeen between the late fourteenth and early sixteenth century - as part of 'the rise of later medieval consumerism that has been charted in other parts of Europe'. As in late medieval Rouen, credit networks based on personal trust were omnipresent in this Scottish city, and ordinary people engaged in small transactions on a daily basis, sometimes even pawning off possessions that they could hardly do without, such as certain pieces of clothing. Gemmil further shows that these clothes not only had a functional purpose, but that they also had a symbolical meaning for ordinary medieval Aberdonians, as a means to display membership of urban society ('Debt, distraint,

\footnotetext{
${ }^{2}$ C. and H. Geertz, Meaning and Order in Moroccan Society: Three Essays in Cultural Analysis (Cambridge, 1979).

${ }^{3} \mathrm{~A}$ notable exception is A. Greif, Institutions and the Path to the Modern Economy: Lessons from Medieval Trade (Cambridge, 2006).
} 
display and dead men's treasure: material culture in late medieval Aberdeen', Journal of Medieval History, 46 (2020), 350-72). Katherine Anne Wilson, finally, offers an excellent interdisciplinary study on the role of chests in late medieval commerce. Akin to Daniel Lord Smail's seminal work on medieval containers, ${ }^{4}$ Wilson engages with the conceptual framework of 'thing theory' as developed by Bill Brown - the idea that seemingly innocuous objects acquire multiple meanings as they are drawn into social relationships with human subjects, other things and specific spaces. ${ }^{5}$ The material nature of chests - as ' $[\mathrm{t}]$ he very things used to store and display money, advance loans, and preserve records of debts' - stimulated 'face-to-face transactions, not faceless credit, and ensured that a significant volume of trade remained focused on personal, public, and socially sanctioned interactions'. At the same time, medieval chests became the embodiment of moral anxieties surrounding the rise of consumerism; not just in terms of their connection with frivolous spending, but also in terms of their association with crippling debts. Reading Wilson's article conjures up a provocative image of two medieval traders huddled together over a chest, which could very well contain great riches or delectable consumer goods, but could just as well contain a bond for a metaphorical pound of flesh ('Commerce and consumers: the ubiquitous chest of the late Middle Ages', Journal of Interdisciplinary History, 51 (2021), 377-404).

All things considered, the number of publications on medieval urban history was somewhat more restricted than the flood of articles of the last two years or so, but the quality of these contributions is certainly no less than before. Current scholarship continues the recent trends towards growing attention to space as an analytical category, the dissolution of the old fragmentation of scholarship in segmented clusters of 'social', 'political', 'economic' or 'cultural' history and, last but not least, a growing commitment to a broader, more inclusive perspective on identities than was common in the previous century.

\section{0-1800}

In eighteenth-century Lyon, the second-largest city of France, the urban textile sector was dominated by the local silk industry. In the second half of the century, the latter was affected by a severe economic crisis. Anne Montenach studied the registers of the police des métiers and the archives of the Grande Fabrique and analysed how working conditions and remunerations changed for the female labourers. In 'Coping with economic uncertainty: women's work and the protoindustrial family in eighteenth-century Lyon', Continuity and Change, 35 (2020), 33-52, she examines which strategies women used to cope with this difficult circumstances. She finds, for example, that wives of masters worked illegally on the loom, taking advantage of skills often acquired informally in the home. In addition, they could rely on family and professional networks or became involved in illicit market practices which were more or less tolerated by the authorities, since this provided sustenance for the most needy. With her contribution, Montenach sheds some

\footnotetext{
${ }^{4}$ Daniel Lord Smail, Legal Plunder: Households and Debt Collection in Late Medieval Europe (Cambridge, MA, 2016).

${ }^{5}$ B. Brown, 'Thing theory', Critical Enquiry, 28 (2001), 1-22.
} 
light on licit and illicit coping mechanisms to gain some income, but, more importantly, she gives centre stage to social groups which are seldom mentioned in other sources.

The following contribution also concentrated on female workers. Studies of the wage gap between male and female earners are hindered by a lack of source material. However, Mauricio Drelichman and David González Agudo found a unique history lab in the case of early modern employment records of the Tavera's hospital in Toledo ('The gender wage gap in early modern Toledo, 1550-1650, Journal of Economic History, 80 (2020), 351-85). These records provide sufficient information for a detailed reconstruction of the remuneration of both male and female nurses. Moreover, the authors were also able to establish that male and female nurses performed identical tasks and were capable of identical productivity levels given adequate patient numbers. Therefore, the reconstruction of the compensation history of male and female nurses, combining detailed data on monetary payments and in-kind remuneration, shows that female nurses received between 70 per cent and 100 per cent of male total earnings. The independent variable predicting the wage gap was the supply of female labour. Variations in female compensation levels were dictated by the relative shortage or abundance of female labour as well as other social constraints on female workers, which the authors called 'pre-market discrimination'. Moreover, the data used by Drelichman and Agudo show a large literacy gap between men and women. Whereas almost 70 per cent of the male nurses could sign their name next to their payroll entries, none of the women could. This difference might explain the willingness of female nurses to work for lower wages, hindered by the lack of other opportunities, and therefore causing the gender wage gap.

Judy Z. Stephenson presents a continuation of recent discussions captured in this periodical review last year. She has written a new article that provides information and data on the work and pay of skilled and semi-skilled men on a large London construction project in the early 1700s ('Working days in a London construction team in the eighteenth century: evidence from St Paul's Cathedral', Economic History Review, 73 (2020), 409-30). Although the empirical evidence is based on one firm only, she brings new insights as to the number of days worked per year and per week. Contrary to current estimates, she shows that employment was more irregular and seasonal. Notwithstanding the narrow empirical base, Stephenson argues that her findings do have some bearing on theories about industriousness and industrialization. As we have explained in the last two review articles, some studies of early modern labour explain industrialization through the high wage theory. Robert $\mathrm{C}$. Allen states that high wages were a fundamental reason for the technological breakthroughs of the eighteenth century, leading to industrialization, during which process capital and energy substituted labour. Because builders' day wages provided evidence for the urban wage data used to explain this transition, recent studies of builders' wages shed new light on the matter. Stephenson emphasizes that when builders earned less per day and for fewer days as she has found, then annual incomes would have been about 40 per cent lower than the current estimates. Again, questions may be raised around the usefulness of builders' wages in estimating increased 'industriousness' and by implication economic growth. 
Nevertheless, the predominance of builders' wages in real wage reconstructions remains, as we can see in the following article. In his classic study on the industrious revolution, Jan de Vries argues that the rising demand for new and cheaper consumer goods triggered eighteenth-century Europeans to work for longer and harder. For de Vries, these two processes are really intertwined. However, Kathryn E. Gary and Mats Olsson see an alternative explanation for any increase in labour output at household level, namely that labourers were forced to work more to make ends meet ('Men at work. Wages and industriousness in southern Sweden 1500-1850', Scandinavian Economic History Review, 68 (2020), 112-28). An indication of this could be that day labourers' relative wages decreased over time. The authors collected a large sample of rural wages paid to unskilled men both in annual employment and to men who worked in the casual construction industry. The sample of urban workers employed annually was taken from individuals working for municipalities or for churches and all unskilled causal labourers were construction workers, both in the country and in urban areas. Yet again, builders' wages take centre stage.

The authors came to the conclusion that up until the mid- to late eighteenth century, a man relying on casual work would have been able to meet his annual needs with far fewer work days than an annually employed man was expected to work. He could then spend the rest of the year working on domestic production or at leisure. But after this period, increasingly more work was needed to earn the same cash equivalent as an annually employed man or to maintain respectability. Additional income could be earned by working more days or by relying on the labour input of family members: 'Especially during the last two decades of the 1700s, additional work from other family members was necessary.' These findings led to the conclusion that 'an increase in industrious behavior through the eighteenth century, though not in order to decorate the workers' homes or indulge in new finery' (p. 126).

Meanwhile, another discussion thread has emerged in the world of wages series. In an earlier article, Jane Humphries and Benjamin Schneider used archival and printed primary sources to construct the first long-run wage series for hand spinning in early modern Britain. Yet again, their findings challenged Robert C. Allen's claims in the high wage theory, which implies that high wages (in this case of spinners) led to mechanization in eighteenth-century England. Humphries and Schneider found empirical evidence of low spinners' wages, meaning that an incentive to replace labourers by machines was lacking. They could not therefore endorse a trajectory to mechanization and especially the spread of the spinning jenny based on the high wage theory. In his reply, Robert C. Allen refutes the critique by providing new evidence that confirms his estimates of (high) wages of spinners (see 'Spinning their wheels: a reply to Jane Humphries and Benjamin Schneider', Economic History Review, 73 (2020), 1128-36). However, these new data are yet again challenged by Humphries and Schneider. They argue that his estimates were based on an ahistorical account of spinners' work and emphasize that wages were low even compared with other women workers ('Losing the thread: a response to Robert Allen', Economic History Review, 73 (2020), 1128-36). We cannot predict the future, but it is fair to state that this debate will stay recurrent.

How inclusive were early modern craft-guilds? Were they open for neophytes, who had no family relation to the more settled masters, or newcomers from out 
of town? Drawing on evidence from more than 100,000 masters, and even more journeymen, from cities in every corner of Europe, Maarten Prak et al. aim to provide a more conclusive answer to these classic questions in their latest article: 'Access to the trade: monopoly and mobility in European craft guilds in the seventeenth and eighteenth centuries', Journal of Social History, 54 (2020), 421-52. Although the offspring of masters were favoured above other greenhorns in the regulations of craft-guilds in most European regions from Bristol to Vienna, or from Gdansk to Madrid, these fils à papa were in most cases only a small minority - at most one third - of all members. The same held true for local born citizens, who were in most cases eclipsed by out-of-town newcomers. Thanks to their comparative methodology, Prak et al. are also able to single out some causes and eliminate others. Urbanization was an important factor in shaping the inclusiveness of craftguilds, as large cities simply needed thousands of foreigners to sustain their population and labour market. Moreover, these urban behemoths struggled - or simply failed - to close all the back doors for migration.

The findings of this article corroborate some of the conclusions drawn by Marjolein Schepers in 'From nativism to the inclusion of immigrants: settlement and poor relief in eighteenth-century Bruges', Journal of Migration History, 6 (2020), 151-81. Bruges and some other Flemish cities abruptly opted out of the Ypres Concordat in the late eigteenth century, which was based on the principle of nativism in poor relief, whereby paupers were sent back to their place of birth. Instead, a settlement in the place of residence was adopted. Schepers shows how this revolutionary policy was based on estimates about the high costs for repatriation, the lack of control, the needs of the local economy and other considerations. Based on a completely different set of political, socio-economic and geographic variables, other Flemish cities, especially at the French border, argued against opting out of the Concordat. Both camps - exit versus remain - were well aware of the various factors that should inform their migration policy.

Migrants - especially the poorer sort - are also ubiquitous in the recent analysis of the seventeenth-century Kirk Sessions of Canongate (near Edinburgh), where prostitutes, thieves, thugs and other riff-raff were tried by the dozen (Alice Glaze, 'Santioned and illicit support networks at the margins of a Scottish town in the early seventeenth century, Social History, 45 (2020), 25-51). As harbouring these women (and men) with a tainted reputation was considered illegal too, the proceedings of the church court also shed light on the magnitude and flexibility of these illicit support networks. Despite the risks involved, relatives, neighbours, friends, colleagues and acquantainces often took pity on these outcasts and provided housing, jobs and other assistance. While the Kirk Sessions shed light on abuse, exploitation and other forms of ill-treatment, they also evidence more altruistic motivations of compassion and benevolence. Due to these underground networks, pariahs could remain unnoticed for several years. Glaze's article reminds us that the official network of poor relief was just one side of the medal. To understand solidarity in full, we also have to scrutinize these illicit support networks in detail.

Complex relationships are also part and parcel of Dag Lindström's latest work on cohabitation in the Swedish town of Linköping in the late eighteenth century ('Families and households, tenants and lodgers: cohabitation in an early modern Swedisch town, Linköping', Journal of Family History, 45 (2020) 228-49). With 
barely 3,000 inhabitants, Linköping was a far cry from a metropolis such as London. However, even in this small Swedish town, families, tenants and lodgers lived together in rather complex households, as the Mantalslängder (the tax rolls) and the Tabellverket (population registers) show. Classic families - mother, father and two or three children - were not uncommon in Linköping, but there were also many larger households, where several families, widows with children and singletons lived together. It seems that these complex cohabitation patterns were, at least, in part stimulated by a steady increase in population in the late eighteenth century. Migration from the countryside forced people to share their houses in ever more complex cohabitation patterns.

Lindström's article benefits from recent developments in GIS methodology. The same holds true for the SIGParis 18-19 project ('Spacialités sociales à Paris à la veille de la révolution. Les apport d'un système d'information géographique' Histoire Urbaine, 58 (2020) 157-86). In their latest article, Anne Varet-Vitu and her colleagues provide a fascinating insight into the ambitious project to link more than 23,000 adressess in late eighteenth-century Paris to the social profile of the master (or lady) of the house. Despite the social bias - the project draws evidence from almanacs, directories and other sources, which shed light on the upper and middle tiers of society - the database helps to locate all sorts of professions and occupations in space. In the article, Varet-Vitu et al. explore the possibilities of various methodologies - hot spots, isotopes, proximity indexes, and so on but also present some preliminary results. Bakers, butchers and charcutiers were, for instance, located along the main thoroughfares, while all sorts of horse-related occupations - coachmen, farriers, carters - shunned the crammed city centre, as space was essential for their profession. Tailors were not as evenly spread over Paris as other craft-guilds, but flocked together in some fashionable streets. Lawyers and barristers preferred the districts around le Palais or the Quartier Latin.

London rather than Paris is the focus of Avital Lahav's analysis of the various plans which were drawn up in the direct aftermath of the Great Fire in 1666 ('Quantitative reasoning and commercial logic in rebuilding plans after the Great Fire of London, 1666', Historical Journal, 63 (2020), 1107-31). Even though these maps have been closely scrutinized in the past, Lahav provides a fresh perspective in several ways. First and foremost, the designs were innovative as they all relied on mathematics to make the most of the available space. The size of the plots, the number of houses, the width and length of major and minor streets: these were all meticulously and painstakingly calculated. Moreover, in planning the new metropolis, priority was not so much given to aesthetic, architectural and urbanist principles, rather the design was fuelled by radically new ideas about the economic rationale of London, being the new warehouse of Europe. Warehouses were for instance planned along a seemingly endless quay at the Thames to minimize travelling distance and transportation costs, while a series of public markets was projected in the commercial districts. Together, the sketches reveal a deeper, transformative understanding of the mechanism of the real estate market, as the idea struck root that the value of a plot of land was all but static given its size and location - but, with some tinkering, could be increased.

Location is also an important topic in Julia Merrit's recent analysis of the shooting club of the Westminster Military Company ('Voluntary military organizations, 
associational life and urban culture in modern England', Seventeenth Century, 35 (2020), 693-714). According to Merritt, the location and facilities of the company's hall should be interpreted as one of the many 'experiments in public sociability', as it stood on the same footing as the Spring Gardens, Shaver's hall and other popular leisure venues for the middle class. Interestingly, Merritt also takes a material turn by focusing on the fashionable design of the 'fair chamber' (the assembly room), with its luxurious furniture, Portland stone doorposts and bluestone fireplaces, the armory, the kitchen and the library. These last amenities make it likely that members not only attended the club for shooting, but also for other forms of sociability. A material turn is also part and parcel of Daniel Maudlin's article 'Inns and elite mobility in late Georgian Britain', Past \& Present, 247 (2020), 37-76, which encompasses countryside inns, inns in small market towns, and inns in the metropolis. Inns, as he shows, spread rapidly across the length and breadth of Britain in the late eighteenth century. From Southampton to Inverness, these roadside inns provided a hallmark of quality, politeness and predictability with their classy interiors and amenities, including mahogany furniture, large fireplaces, crystal glasses, exclusive wines and good food, and comfortable beds with clean linen, pillows and blankets. Together with the nascent transport (r)evolution of turnpike roads and diligences, the expanding networks of inns enabled genteel travellers to tour Britain in an unprecedentedly comfortable, safe and speedy way. Mobility - smaller trips but also longer tours through England, Scotland and Wales - became part and parcel of the genteel lifestyle.

While Daniel Maudlin reflects on how British cities reached out to the countryside through a dense network of inns and coaches, Mark Hailwood look at the influence of urban time on some rural counties in south-west England ('Time and work in rural England, 1500-1700', Past \& Present, 248 (2020) 87-121). Drawing on the evidence of more than 15,000 quarter sessions depositions, church courts and coroners' reports, Hailwood looks critically at the E.P. Thompson's classic hypothesis that people's sense of time was still largely attuned to the stations of the sun before the industrial revolution. Moreover, work rhythms would have been irregular and variable throughout the day, the week and the year. Hailwood persuasively debunks these ideas. Even though natural markers of time were still important, clock time was definitely on the rise in early modern rural England. Labour rhythms were all but irregular. Work did not cease on Saint-Monday - traditionally thought as a part of the weekend - nor did it show significant seasonal variations. Urbanization - although indirectly, as these rural regions were connected to towns and cities - fostered a keen awareness and use of time. Time in the metropolis is also scrutinized by Gerrit Verhoeven in 'Clockwise? Timekeeping in London in the long eighteenth century (1725-1825)', Cultural and Social History, 17 (2020), 451-71. Verhoeven explores the proceedings of the Old Bailey to uncover some slow-burn - or even glacial - evolutions in everyday timekeeping in the long eighteenth century. Pluritemporality - the classic mix between natural, social and clockbased markers of time - only slowly gave way to a mechanical notion of time, whereby a direct link to the spread of pocket-watches and other private timepieces seems to be missing. Verhoeven also argues that the timekeeping of men and women, upper-, middle- and lower-class Londoners was not poles apart, as one might imagine given the rather socially skewed distribution of watches and other 
private timepieces throughout society. Public beacons of time - bells on churches, town halls and city gates - were much more important in this regard.

Time awareness is also an issue in Daniel Jütte's fascinating research on boredom ('Sleeping in church: preaching, boredom and the struggle for attention in medieval and early modern Europe', American Historical Review, 125 (2020), 1146-74). Jütte argues that tedium is often seen as a modern feeling without a history or, at least, without a 'deep' early modern history. Gathering evidence from diaries, moral treatises, caricatures and other sources on the endemic problem of sleeping in church, Jütte argues that ennui was already widespread in the sixteenth and seventeenth centuries, as the congregation was often bored stiff by the dull and insipid sermons of the vicar. Tedium was not only an issue of the elite - the leisure class - but also affected middle- and lower-class churchgoers. Sleeping was not the only problem in church, as reports also referred to the congregants' constant toing and froing. Talking in church was even an issue in complaints lodged at the Star Chamber in London. Francesca Cioni shows how disputes about schmoozing and seating arrangements in church were tied to ideas about social hierarchy and public order ("Confuse noises, and clatterings": fixed seating and disorderly worship in England, 1604-1632', Seventeenth Century, 35 (2019), 557-77). Every attempt to tinker with the arrangement of the pews was met with hostility, as it put the traditional pecking order in town into question. Early modern people were thus prepared to defend their fixed seat in church at all costs and - if the worst came to the worst - even in court.

Cioni's article makes clear that the brethren in church were not really seen as equals. Even the seating arrangements reproduced clear-cut social inequalities. Matthew Laube shows that music served a similar purpose in German churches ("The harmony of one choir?" Music and social unity in reformation Heidelberg', Past \& Present, 248 (2020), 41-86). Focusing on the differences between parishes in Heidelberg, where the upper- and middle-class congregation of Heiliggeistkirche and the Barfürßerkirche contrasted with the more popular Peterskirche and Spitalkirche, Laube argues that congregational singing duplicated social inequalities. The key to the quality of the music was, for instance, the boys choir. While the more bourgeois parishes appealed to the Latin school and the Pädagogium, where the boys received daily instruction in music, the Peterskirche and Spitalkirch had to be content with less practised voices. At the same time, the different soudscapes of these churches were also influenced by the unique size and architectural design of the church. Music did not bridge social differences between churchgoers but rather replicated them.

An interest in church music is part and parcel of the history of the senses. That is also the line of approach taken by Louise Deschrvyver in her latest research on Protestant burial culture in French Flanders ('You only die once: Calvinist dying and the senses in Lille and Tournai during the Dutch Revolt', Early Modern Low Countries, 4 (2020) 35-57). Drawing on evidence from Pierre Viret's L'office des morts (1552) and other how-to-books on dying in a proper Protestant way, Deschryver analyses how Calvinist quibblers made short shrift of the Catholic burial ritual by denouncing the burning of candles, the use of incense, the tolling of bells and other sensory expressions. Deschryvers also looks at how these moral prescriptions were put into practice. Calvinist martyrs, for instance, deliberately looked 
away from the crucifix when they were mounting the scaffold or sung psalms to drown out the Catholic prayers. Wherever Protestants were in power, these Calvinist ideals also affected burial practices. Yet, even the staunchest adherents usually steered a middle course between Catholic and Calvinist rites.

\section{Post-1800}

Among other things, 2020 will be remembered for the Black Lives Matter protests against police brutality in the United States, which reverberated in the streets of many western metropolises. Historically, there have always been tensions between urban police forces and the people they are supposed to serve and protect, which might be exemplified by the fact that police officers rarely live in the districts in which they work. Holding officers accountable for the law is difficult for obvious reasons. As Anja Johansan demonstrates in 'Beyond the reach of law? Criminal prosecution of Parisian police personnel, 1872-1914', Journal of Modern History, 92 (2020), 485-520, this was already a problem in the French capital during the Third Republic, when it was nearly impossible to prosecute local policemen for misconduct while on duty. Johansan uses case-studies in which officers used excessive force, often resulting in fatalities, to demonstrate how the practice of not prosecuting policemen in Paris and other French cities became increasingly at odds with the situation in Britain and Prussia, leading her to question further French republican values of the time. The conduct of the Parisian police force was also questionable during World War II, when it was highly effective in deporting the local Jewish population. Unlike other European cities under occupation, the Germans entrusted the deportations to the traditional administration, as Laurent Joly examines in 'The Parisian police and the Holocaust: control, round-ups, hunt, 1940-4', Journal of Contemporary History, 55 (2020), 557-78. Yet this did not mean Parisian officers were ardent anti-Semites, nor did they enjoy co-operating with the German occupiers. According to Joly, it was an obedient work ethic already in place that made policemen follow up orders.

In the introduction to a timely special section on urban American police departments, 'Crisis and redemption: the history of American police reform since World War II', Journal of Urban History, 46 (2020), 951-60, Christopher Lowen Agee discusses the multiple crises in police legitimacy during the post-war era. He identifies three distinct periods of disruption for local police departments: the 1950s and 1960s, when the close relationship between political machines and law enforcement began to break down while black inner-city populations became increasingly criminalized; the 1970s and 1980s, when the carceral state emerged and broad coalitions came together to expand policy authority by means of surveillance and repression; and the 1980s until now, a period in which the federal government initially cut back local budgets but soon equipped police with heavy arms in the so-called war on drugs. Stuart Schrader in 'More than cosmetic changes: the challenges of experiments with police demilitarization in the 1960s and 1970s', Journal of Urban History, 46 (2020), 1002-25, goes to show that police militarization during the two latter periods was not a unilinear development, with some departments choosing to reform and actually investing in partnerships with black communities. In the New York of the 1980s and subsequent decades, however, a harder line was adopted 
by implementing broken windows policing and the promotion of an orderly city as a precondition for prosperity, which is what Themis Chronopoulos demonstrates in 'The making of the orderly city: New York since the 1980s', Journal of Urban History, 46 (2020), 1085-116. These new policies - embraced by then Mayor Giuliani - rested on morally and legally questionable actions such as racial profiling, and the correlation between affluence and safer streets remains disputable. To say the relations between black residents of British cities and local police are also tense is an understatement, as might be exemplified by the 2011 riots in London and other places and, less recently, the Moss Side riots in Manchester. Shirin Hirsch and David Swanson in 'Photojournalism and the Moss Side riots of 1981: narrowly selective transparency', History Workshop Journal, 89 (2020), 221-45, examine contemporary photographs as active commentaries that 'alter, enlarge and restrict our notions of what is worth looking at and what we have a right to observe'.

The Black Lives Matter protests were overshadowed by that other disruptor to the everyday urban experience, the outbreak and rapid spread of COVID-19. Some commentators labelled the subsequent social crisis and economic downturn 'the great equalizer' and lamented a loss of urban community and public life, while others said the situation only laid bare the inequality in urban societies, with knowledge workers enjoying afternoon strolls in between Zoom calls whilst others were still forced to commute to work, deliver food, clean and police the streets and take care of the sick and elderly. Postal workers were particularly vulnerable to infections and high levels of stress. Taking this profession as a sample group for changing morbidity patterns in Victorian London, Douglas Brown et al. in 'The beating heart of the system: the health of postal workers in Victorian London', Journal of Historical Geography, 68 (2020), 75-85, conclude that alongside age other influences on the incidence and duration of ill health need consideration, amongst others urbanization, occupational risks and institutional factors - a proper urban history approach to changes in local health conditions. In the same journal, by using epidemiological techniques, GIS and archival records, Emily Webster in 'Tubercular landscape: land use change and Mycobacterium in Melbourne Australia, 1837-1900', Journal of Historical Geography, 67 (2020), 48-60, analyses how the alterations of Melbourne's landscape to accommodate sanitary infrastructures actually exacerbated the transmissibility of tuberculosis, thus challenging common sense that such measures would only improve urban health.

Melbourne was of course not the only city to undertake massive sanitary improvements in the nineteenth century. By examining data from a large number of German cities, Daniel Gallardo-Albarrán is similarly critical of the assumption that the construction of water works benefited each and every one equally ('Sanitary infrastructures and the decline of mortality in Germany, 1877-1913', Economic History Review, 73 (2020), 730-57). The reduction in the number of deaths due to the supply of safe drinking water was lower than previously suggested, and its effects were less impactful in poor communities and cities located in non-Prussian territories. In the same journal, Romola Davenport reviews the historical relationships between urbanization and epidemiological trends in England in 'Urbanization and mortality in Britain, 1800-50', Economic History Review, 73 (2020), 455-85. While she does confirm mortality increase in the second quarter 
of the nineteenth century, this was not unique to industrial boom towns and urbanized areas in general. Mortality worsened around this time, in particular for young children, but - contradictory to what has been argued before - this was not so much the result of deteriorating living conditions in urban environments. For a more recent time period, Sarah Taylor comes to the conclusion that exposure to air pollution in childhood leads to excess mortality at an older age by comparing mortality rates among an impressive 390,000 individuals born in Pennsylvanian steel towns between 1916 and 1927, 'Growing up in a steel town: early-life pollution exposure and later-life mortality', Social Science History, 44 (2020), 117-42. Perhaps not surprisingly, the more steel a town produced and the lower its elevation, the more pollution and the higher the mortality rates. Planning has always been an important tool in improving urban health, for example by introducing single-use zones and greenbelts. Taking a long-term approach to the intrinsic links between public health and urban planning, Melissa Hensley et al. examine how health concerns have influenced Brisbane's morphology in 'How diverging interests in public health and urban planning can lead to less healthy cities', Journal of Planning History, 19 (2020), 71-89.

One unpopular measure to halt the spread of COVID-19 this year was the nightly curfew, which was enforced in many countries with high infection rates. Throughout most of the nineteenth century, Rio de Janeiro went quiet after 10:00 p.m. as well - the result of a curfew applied to enslaved persons that went into effect just after Brazil gained independence in 1822. Amy Chazkel in 'Toward a history of rights in the city at night: making and breaking the nightly curfew in nineteenth-century Rio de Janeiro', Comparative Studies in Society and History, 62 (2020), 106-34, demonstrates that despite prohibitions to enter public spaces during the night there was a bustling nocturnal economy and vibrant social life. Indeed, in the words of Chazkel, the curfew established patterns and means of limiting the basic freedom to move about the city. Yet it did not halt all movement after dark but rather instituted a reign of selective policing. If we want to understand such practices of urban governance and the exercise of local power, we need to look beyond the newly minted nation-states of the nineteenth century. However, another Brazilian case-study set in a period when the nation-state's power was already dwindling shows that architecture has always been a tool in articulating state power and nationalist feelings. In 'Brutalism and the people: architectural articulations of national developmentalism in mid-twentieth-century São Paulo', Comparative Studies in Society and History, 62 (2020), 296-326, José Bortoluci explores the intrinsic links between Brazil's post-war national developmentalism and social housing policies in the context of São Paulo's urbanization and construction boom. Because architects and state officials solely understood the city's housing crisis as a quantitative issue, they became alienated from the urban poor for whom they were actually building.

Class issues and the plight of the urban poor are also featured in a number of other research articles this year. Rowena Gray in 'Inequality in nineteenth-century Manhattan: evidence from the housing market', Social Science History, 44 (2020), 571-82, innovatively overcomes the methodological issue of measuring historical inequality by collecting rental prices from newspaper advertisements, which she uses to demonstrate how much of New Yorkers' consumption expenditure was 
spent on housing between 1880 and 1910. By geocoding her observations, Gray also substantiates her argument that inequality within Manhattan neighbourhoods was much greater than between neighbourhoods, which is still the case in many American cities. In New York, the solution for inequality in the local housing market was found in public housing, which was introduced in the 1930s under the auspices of the New Deal programme. Between 1934 and 1940, the United States government developed more than 30,000 social housing units. An impressive number, but quantity is not what Ryan Allen and David van Riper are interested in primarily in 'The New Deal, the deserving poor, and the first public housing residents in New York City', Social Science History, 44 (2020), 91-115. They put a human face on the numbers by looking into who was considered eligible for public housing during the inter-war period. The results demonstrate a shift towards lower-income households, a continuous preference for the nuclear family, the pursuit of racial segregation and a preference for native-born citizens.

The introduction of social housing was also a means to discipline the working classes, but there have been more inventive and unexpected ways to regulate the behaviour of the less-well-off. A typically Victorian intervention was the introduction of flower missions, flower shows and window gardening to uplift the spirit and material conditions of London's working poor, which Anna Lawrence connects to the 'moral botany' of the early nineteenth century in 'Morals and mignonette; or, the use of flowers in the moral regulation of the working classes in high Victorian London', Journal of Historical Geography, 70 (2020), 24-35. With her contribution, Lawrence argues for more environmental consciousness in urban history. The 'flowering' of London's workers was a heavily gendered practice, which also holds true for men working in reserved occupations during World War II in Glasgow and Clydeside. Based on oral histories, Alison Chand, 'Belonging to Glasgow and Clydeside in the Second World War: retrieving regional subjectivities among male civilian workers', Cultural and Social History, 17 (2020), 537-67, examines their attachment to local and regional subjectivities as opposed to pride over contributing to the British war effort. Her contribution reveals a strong sense of individual and social agency in the everyday urban experience that was only marginally tied to the experience of war, thus further complicating the notion of World War II as a catalyst for social change. Mikkel Høghøj in 'Aarhus as a welfare geography: urban modernism and shaping of "welfare subjects" in post-war Denmark', Planning Perspectives, 35 (2020), 1031-53, investigates the emergence of the Danish welfare regime as a radical influence on the post-war landscape of Aarhus and by extension the city's everyday life. Indeed, the local planning agenda came to function as an instrument of urban governance that negotiated and (re)produced social citizenship.

Urban redevelopment was one of the means by which the welfare state tried to create order out of a perceived disorder. While historiography has mostly focused on grand schemes for capital cities and metropolises, David Hochfelder and Dougls Apple in 'Introduction to special issue on urban renewal in smaller cities', Journal of Planning History, 19 (2020), 139-43, shift the attention towards middle-sized cities and towns. By doing so, they hope to connect local stories to a larger national history of the post-war city and to embed them in a longer time horizon. In the United States, these stories have often been connected to racial segregation, as 
Lauren Pearlman demonstrates in 'The Bicentennial and the battle over DC's downtown redevelopment during the 1970s', Journal of Planning History, 19 (2020), 207-27, and Rebecca Retzlaff in 'Connecting public school segregation with urban renewal and interstate highway planning: the case of Birmingham, Alabama', Journal of Planning History, 19 (2020), 256-80. Pearlman examines the execution of a major redevelopment scheme in Washington DC as a project that divided the local black community between those who embraced a pro-growth agenda in coalition with private developers, and those who saw no benefits for the mostly black residents who lived in the vicinity of a brand-new convention centre the redevelopment scheme's showpiece. Retzlaff argues that the rollout of the interstate highway system during the post-war period was used as a pretext for preserving segregated schools in Birmingham, Alabama - reminiscent of the ways in which Robert Moses tried to keep New York segregated through expressway planning.

Also set in the Southern United States is Sophie Kahler and Conor Harrison's "Wipe out the entire slum area": university-led urban renewal in Columbia, South Carolina, 1950-1985', Journal of Historical Geography, 67 (2020), 61-70, which highlights the questionable role universities played in destabilizing African American communities. On a much broader scale, Christine Leibbrand et al. in 'The great migration and residential segregation in American cities during the twentieth century', Social Science History, 44 (2020), 19-55, suggest that African Americans originally living in Southern states experienced few residential and economic benefits from moving to industrial powerhouses in the north and elsewhere, which was due to both segregation and deindustrialization. Industrial decline, albeit in a different geographic context, was also the topic of a special issue compiled by Jörg Arnold, Tobias Becker and Otto Saumarez Smith, 'The de-industrializing city in the UK and Germany: conceptual approaches and empirical findings in comparative perspective', Urban History, 47 (2020). Another instance of racialized urban redevelopment on the North American continent was the demolition of Chinatowns at the beginning of the last century, which is the topic of Domenic Vitiello and Zoe Blickendorfer's article 'The planned destruction of Chinatowns in the United States and Canada since c. 1900', Planning Perspectives, 35 (2020), 143-68.

In Europe, urban redevelopment came on the heels of the destruction wrought by World War II, the carpet bombing of cities in particular. Historians have failed to connect the European and Asian theatres of war but the American proponents of strategic bombing campaigns certainly did, posits Sheldon Garaon in 'On the transnational destruction of cities: what Japan and the United States learned from the bombing of Britain and Germany in the Second World War', Past \& Present, 247 (2020), 235-71. The American strategies and tactics against Japanese urban areas were informed by the concurrent bombing of German cities, which - contrary to current historiography - was rather successful in breaking civilian morale. One could say that the bombing offensives provided modernist planners with a clean slate, which in many European cities was further cleared by additional demolitions of historical buildings in the immediate post-war years - dubbed a 'second destruction' by German commentators. Andrew Demshuk in 'A Polish approach for German cities? Cement old towns and the search for rootedness in postwar Leipzig and Frankfurt/Main', European History Quarterly, 50 (2020), 88-127, 
explores the historical reconstruction of Polish cityscapes - often cast in concrete as a model for German cities eager to eradicate modernist rebuilding efforts and restore some of their pre-war splendour. In 'Postmodern reconciliation: reinventing the old town of Elbląg', Architectural Histories, 8 (2020), 1-25, Florian Urban zooms in on the Polish city of Elbląg, which was destroyed during the war but rebuilt from 1979 onwards in a pseudo-historical style. Urban convincingly demonstrates that this building style and its historical roots were very different from postmodernist trends on the other side of the Iron Curtain due to a longing for local identity erased with the Polish takeover of Germany's former eastern territories, which is also his line of argumentation in 'Postmodernism and socialist mass housing in Poland', Planning Perspectives, 35 (2020), 27-60. A similar case-study of the politics behind urban destruction and renewal is presented by Marcus Colla in 'Memory, heritage and the demolition of the Potsdam Garnisonskirche, 1968', German History (2020), 38, 290-310. Colla embeds the demolition of a Prussian church into a broader narrative of East German attitudes towards a tainted past, and how the latter resurfaced in the GDR's heritage and legacy policies.

This year, Planning Perspectives published a good number of articles on architecture and urban planning during the Cold War, with a focus on (post)socialist countries. Sujin Eom in 'Infrastructures of displacement: the transpacific travel of urban renewal during the Cold War', Planning Perspectives, 35 (2020), 299-319, argues that the American and South Korean regimes of the post-war period saw urban space as a means to foster anti-communism and urban renewal as a 'geopolitical project' of disseminating ideas, norms and technologies of governing cities. Taking a long-term perspective, Olga Siegmunt critically discusses socialist housing policies in Russia from 1917 until the end of the Soviet period in 'The historical development of the housing policy of Russian cities from pre-industrialization period to free real estate market', Planning Perspectives, 35 (2020), 955-68. Dalia Dukanac and Ljiljana Blagojević show that in late socialist Belgrade, modernist architects with an educational background in western countries came up with alternative designs for the mass housing slabs of the first post-war decades in 'Spaces of transition: testing high standard housing in late-socialist Belgrade', Planning Perspectives, 35 (2020), 969-1004. Moving on to a more recent time period, Nari Shelekpayev in "Whose master plan? Kisho Kurokawa and "capital planning" in post-Soviet Astana', Planning Perspectives, 35 (2020), 505-23, reveals the ways in which planning strategies and international politics have mutually reinforced each other in the design of a new capital city for Kazakhstan - the only post-Soviet state to relocate its seat of government after the transition of power in the early 1990s.

In Astana, special attention was paid to the layout of public spaces. Throughout urban history, such spaces have been expressions of achievement by urban leaders and visionaries, sites of public encounter and political struggle. Ankara, designated as the new Turkish capital in 1923, is the topic of a long-term study into the design and changing uses of public space in 'Emergence and evolution of the urban public open spaces of Ankara within the urban development history: 1923 to present', Journal of Planning History, 19 (2020), 26-51, by Nevruz Cinar Ozdil et al. Around the same time as Ankara began designing public spaces to reflect the values of a new-born Turkish state, the aftermath of a devastating earthquake provided 
planners in Tokyo with ample room for the creation of public parks that would come to function as playgrounds and exercise grounds, sites of rest, recreation and later emergency refuge. This multifunctional use of public space is also researched by Janet Borland in 'Small parks, big designs: reconstructed Tokyo's new green spaces, 1923-1931', Urban History, 47 (2020), 106-25. Going further back into time, Danielle van den Heuvel et al. in 'Capturing gendered mobility and street use in the historical city: a new methodological approach', Cultural and Social History, 17 (2020), 515-36, present an interdisciplinary approach to analyse how the streets of early modern cities were used and by whom. Van den Heuvel's team are not the only colleagues who have been suggesting new and promising methodologies this year. Richard Rodger and Susanne Rau in 'Thinking spatially: new horizons for urban history', Urban History, 47 (2020), 372-83, propose to deploy new techniques of spatial analysis using mapping tools to explore the features of towns and cities. We can only hope such methodological innovations can soon be brought into practice, when the archives reopen, and urban historians can meet each other again in other spaces than cyberspace.

Cite this article: Buylaert F, Van Der Meulen J, Verhoeven G, Vermoesen R, Verlaan T (2021). Review of periodical articles. Urban History 48, 386-406. https://doi.org/10.1017/S0963926821000031 